\title{
The Spanish-Pacific World and the Jesuits
}

\author{
Christina H. Lee and Ricardo Padrón, eds.
}

The Spanish Pacific, 1521-1815: A Reader or Primary Sources (Amsterdam: Amsterdam UP, 2020). Pp. 249. Hb, €99.oo.

\section{Ulrike Strasser}

Missionary Men in the Early Modern World: German Jesuits and Pacific Journeys (Amsterdam: Amsterdam UP, 2020). Pp. 274. Hb, €99.oo.

In recent years, early modern historians and literary critics have turned to the Spanish Pacific world not simply as the terrain of Catholic imperialism, but rather as a privileged field for cross-cultural encounters. Placing the Spanish Pacific into world histories that emphasize economic and cultural relations between Europe and the East, these two books successfully contribute to our understanding of the connectedness of the Spanish East Indies. In The Spanish Pacific, 1521-1815, Christina H. Lee and Ricardo Padrón offer a varied collection of primary sources, translated into English, that opens up a window to the Pacific, especially to graduate and undergraduate students. The book was published following an interdisciplinary symposium held at Princeton University in 2018. Each author was asked to select a vital area of contemporary research on what was once labeled as "Spanish Lake" (1513-1607), ${ }^{1}$ providing a primary source to be transcribed, edited, and translated, and accompanied by a short introduction.

As the editors claim in the introduction, this collection is the result of a deliberate choice that does not intend to reproduce the same topics, or cliches, as those constructed by E. Blair and J. Robertson, who were fairly criticized for being biased against Catholic Spain (Cleveland, 1903-9), or J. L. Phelan (Madison, 1959), who did not sufficiently recognize indigenous agency (13). At the heart of this admittedly arbitrary process lies an attempt to portray the Spanish Philippines as a colonial "contact zone," to borrow Adorno's words, ${ }^{2}$ where an extensive web of agents and collaborators acted in a multinational

1 Mariano A. Bonialian, "La historia económica del Pacífico en su larga duración una revisión a las Filipinas y el Pacífico de los ibéricos de Pierre Chaunu," Illes i imperis 19 (2017): 77-99.

2 Rolena Adorno, The Polemics of Possession in Spanish American Narrative (New Haven, CT: Yale UP, 2007), 329. 
empire. In this sense, the selections include primary sources that are analyzed not only as historical materials but also as forms of rhetoric, Catholic propaganda (Rodríguez, 141-56) or even literature (Legnani, 157-69). They span the entire history of the Spanish Pacific from European first encounters with southeast islanders to the early nineteenth century, when the last 1815 Acapulco galleon altered the Spanish hegemony in Asian-Pacific possessions. By exploring the interactions and economic and cultural exchanges within colonial trading networks between the peoples of Western Europe, West Africa and the American territories, the Spanish Pacific ushers in a variety of geographical scales, from preexisting local conditions to the regional and global spaces where migrations, long-range commodity exchanges, and cultural transfers in the Eastern Indies took place.

Glimpses of subaltern subjectivities and global mestizajes are particularly provided in these articles, showing the multicultural and multilinguistic nature of life in the Spanish Pacific. First, Juan Cobo's Map of the Pacific World (1593), prepared surely with the help of Chinese collaborators, was conceptualized to establish the authority of Christian culture in the mind of Chinese readers (Padrón, 53-6o). Secondly, Diego de Rueda y Mendoza's Relación (Manila, 1625) provides a pseudo-ethnographic account of a Catholic Chinese wedding in early seventeenth-century Manila, which offers flashes of the culture of sangleyes through Spanish eyes (Martínez, 73-89). Thirdly, the attempt of Luis Castilla, an indigenous Tagalog speaker and member of the local aristocracy or "principalía," to sell various parcels of land, illustrates the rapid implantation of Spanish legal culture in Luzon. The documents of Castilla's dossier combine Spanish with Romanized Tagalog and Tagalog written in the native baybayin script, as well as some Chinese characters, which provide "glimpses of a certain plurality of cultures interacting with each other in early 17th century Manila" (Trota José, 95). Fourthly, Leonor Álvarez, a Peruvian daughter of gentile parents from Portuguese Indies, lived in the multicultural seventeenth-century Lima until she died of natural causes. This case study is unique because it places her in the major economic activities of the imperial and religious administrative center of Peru. Her 1644 will is an example of how indios chinos were able to use legal procedures to their own purposes (Garofalo, 131-40). Finally, Alexo de Castro, a Moluccan soldier of mestizo origin, faced trial by the Inquisition in the New Spain under the accusation of crypto-Islam. In a context of external threats, this case reveals "geopolitical anxieties and local security concerns that were specific to 17th century Manila" (Crewe, 172).

Trade regulations and political and military rivalries among European powers are also reflected in this reader. First, the account of the journey of García 
Jofre de Loaysa's ill-fated expedition to the Spice Islands or Moluccas (1525), by Captain Andrés de Urdaneta (1508?-68), offers valuable information about geography, fauna, and flora of the Philippines and the Moluccas. To this end, it was necessary to evaluate the economic resources offered by the different archipelagos, including the character and nature of the indigenous population (Mojarro, 37-52). Secondly, the 1604 royal decree of Philip III regulating the transpacific trade between Acapulco and Manila laid the ground for the safety and regularity of the galleons' route (Cobo and Seijas, 61-72). Thirdly, a Latin poem (1766) by a Tagalog priest, Bartolomé Saguinsín (c.1696-1772), places the loss of Manila into the context of the Seven Years' War (1756-63), and the subsequent recuperation of the city by Spain. Significantly enough, while Tagalogs, Pampangos, and Bulaqueños were praised for their loyalty to Spain, the Chinese were portrayed as treacherous and having a bio-inclination to violence $(223-38)$.

Finally, evangelization, spiritual politics, and religious affairs are also well represented. Following the leadership of Fray de las Casas (1484-1566), Bishop Domingo de Salazar's (c.1512-94) Memorial (1582) provides insights into the contradictions of the encomienda system, which prevented the evangelization of the natives and Chinese population. Although Salazar never opposed the institution itself, he repudiated all forms of slavery (Lee, 21-35). Thirdly, the 1633 annual letter, written by the procurator Juan de Bueras (1583-1646), informed Superior General Muzio Vitelleschi (in office 1615-45) about the Jesuit activities in the island of Mindoro. He emphasized idolatry and apostasy among the native highland group known as the manguianes, who allegedly lived under the grasp of the devil. ${ }^{3}$ However, primary sources must be always contrasted and not taken for granted. Unlike Bueras's opinion, the Jesuit Diego de Oña, who wrote the censored Labor evangélica (Manila, 1701), declared that the manguianes "no conocían deidad alguna y así eran pocos los sacrificios" (did not know any deity and therefore there were few sacrifices). ${ }^{4}$ Fourthly, in the History of Mindanao and Jolo (Madrid, 1667), a posthumous work on the natural and moral history of the southern Philippines, the Jesuit Francisco Combés (1620-65), reproduced in many ways "the traditionally rejected Muslim Other" (Rodríguez, 143). Fiftly, the Constitutions and Rules of the Beatas Indias (1726) for the foundation of La Compañia, the first beaterio

3 In 1663, the manguianes would be evangelized by the founder of the Marianas, Diego Luis de San Vitores (Francisco de Zambrano, SJ, Diccionario bio-bibliográfico de la Compañía de Jesús en México, [Mexico City: Jus, 1968], 13:778). A Jesuit missionary who was never canonized, as erroneously writes K. Santner (191). He was blessed in 1985 by Pope John Paul II.

4 Diego de Oña, Labor Evangélica: Ministerios apostólicos de la Compañía de Jesús; Segunda Parte, 1701 (ARSI, Philipp. 19-I, Book II, fol. $772^{r}$ ). 
in the Philippines established explicitly for native women, informs the reader about female religious life in eighteenth-century Manila (Santner, 189-204). Sixthly, two different but intimately related texts: dalits, or devotional poems by Tagalog natives praising the work of Catholic missionaries, and an eighteenth-century confessional manual used to administer the sacrament of penance, which embody a different attitude, or spiritual politics, toward the written word in the religious life of colonial Philippines (Rafael, 205-22). The last document, a prohibition on digging up the bones of the dead (1813), was written in local Cebuano and provides evidence of persistence of traditional beliefs and practices in the Visayas (Manalo, 239-44).

Most of the case studies presented above deal with the Moluccas and the Philippines, including southern islands of Mindanao and Sulu, but oddly enough, there is none devoted to the Marianas Islands, which were fundamental to understand the Spanish frontier-geopolitical, territorial, and religious - in the Western Pacific. Certainly, this borderland was the result of an early modern process of globalization. ${ }^{5}$ However, even Western canonical historiography, such as William Lytle Schurz's The Manila Galleon (New York: E. P. Dutton \& Co., 1939), knew about the importance of the island of Guåhan (Guam) as a possession of great strategic value- "a useful landfall" in Rogers' words - in the Manila-Acapulco galleon route, placing it within a global framework of colonial expansion and overgrowth. ${ }^{6}$

Proof of this is the next book under review. Drawing heavily from gender studies, Ulrike Strasser wonders how a remote archipelago in the margins of the Spanish overseas empire turned into a magnet of desire for Spanish and foreign Jesuits, particularly Germans, in the late seventeenth century. The answer is missionary masculinity, a novel gender form to be analyzed "as both an embodied experience of individuals and as a cultural script for other men to re-enact across time and space, generating political, social, and material effects in different parts of the world, through both direct missionary activities and knowledge production" (19). In 1946, Lazaro Aspurz, O.F.M.'s classic book, La aportación extranjera a las misiones españolas del Patronato Regio (Madrid, 1946), had already outlined the contribution of foreign missionaries, especially from German-speaking lands of Central Europe, in the Spanish missions. Nonetheless, the novelty of Strasser's book is the way she links gender history (masculinities, male mimesis) to world or global history in the early modern period. Jesuit missions and missionaries were coded as masculine on domains, like the Mariana Islands, where men

5 Reiner F. Buschmann, Edward R. Slack, Jr, James B. Tueller, Navigating the Spanish Lake: The Pacific in the Iberian World, 1521-1898 (Honolulu: Hawai'i UP, 2014).

6 Robert F. Rogers, Destiny's Landfall: A History of Guam (Honolulu: Hawai'i UP, 1995). 
were apparently the only actors on stage. However, while patriarchal dynamics marked Jesuit history from the very beginning, missionaries were shaped by gender in different yet allegedly contradictory ways. Emotions (or more accurately, passions), for example, are part and parcel of this study of Jesuit masculinities. As Barbara Rosenwein put it, the Jesuit order was an "emotional community" that gave free reign to stirring emotions and desires for action (31). Missionary men inspired novices to imitate-imitare - their illustrious forefathers as well as those Jesuit exemplars who died as martyrs of the Catholic faith into the distant missions. Male mimesis facilitated the Society's extraordinary expansion across the early modern world, allowing for new forms of action by working the human passions (cited on page 32 ).

Chapters 1 and 2 explore the origins of missionary masculinity in Europe and overseas by focusing on the founding fathers. Ignatius Loyola's particular manhood, well reflected in his so-called Autobiography, turned him into the Society's Ur-father, while Francis Xavier became the patron of mobility and metamorphosis $(34,237)$. Through transoceanic voyages, Jesuits had to tame their fears and fortify their spirit. This was not an easy task to do, as some private letters show. ${ }^{7}$ However, I agree with Strasser that any initiation voyage demanded some kind of inner conversion. How much those spirits were transformed is another matter. The issue at stake was the way in which Jesuits accommodated Xaverian experience to specific missionary situations. In the case of Diego Luis de San Vitores (1627-72) and Augustinus Strobach (1646-84), the protagonists of chapters 3 and 4, respectively, ended up tragically: both were animated copies of Francis Xavier and found martyrdom that had eluded the Navarrese saint, thus extending the reach of the order's corporate body in space and time (148-51).

Chapter 5 , the longest yet uneven one, revolves around Jesuit knowledge production about the Pacific as an expression of missionary masculinity. German Jesuit Adam Kaller's Vitae (1688) of Catarina de San Juan turned her into a protective patroness of travelling missionaries approaching the perilous site of the Marianas, while Paul Klein's Palaos map (1697) served to assert the masculine self at the expense of the feminine-inflected mythology of the indigenous people. However, while I agree that Joseph Stöcklein's Der Nue Welt-Bott (1726) fostered German global imagination in Asia (207-26), no less did Charles Le Gobien's History of the Marianas (Paris, 1700) and Charles Le Gobien and Pierre du Halde's Lettres édifiantes et curieuses (Paris: Nicolas Le Clerc, 1715-55), but for a Spanish-French audience. ${ }^{8}$ Both editors, who, by the way, never put their

7 Alexandre Coello and David Atienza, eds., Scars of Faith: Jesuits Letters from the Mariana Islands (1668-1684) (Chestnut Hill, MA: Institute of Jesuit Sources, 2020).

8 Luis de Morales and Charles Le Gobien, History of the Mariana Islands, ed. Alexandre Coello (Mangilao, Guam: Guam UP \& MARC, 2016). 
feet on the Pacific islands, were not only defending Europe's religious civilizing mission, but also imperial anxieties of their respective countries in Asia and the Americas. In the case of German Jesuits, their missionary dreams were satisfied through others' overseas empires until the late nineteenth century. However, as Strasser points out, German contribution to shape an increasingly connected world should not go unnoticed (240).

To sum up, these two books are an example of the growing interest of scholars in the Spanish Pacific. The first one, a reader's digest that include a diverse selection of sources, often abridged, is addressed to a broader audience than the second one, a rich and beautifully crafted work that deals with missionary manhood as a novel European gender form that arose alongside that of the conquistador in the context of early modern colonization. Both books contribute, at different levels, to our understanding of the complexities of Iberian colonization and missionary self-fashioning in the Spanish East Indies.

\author{
Alexandre Coello de la Rosa \\ Universitat Pompeu Fabra, Department of Humanities - ICREA Academia, \\ Barcelona, Spain \\ alex.coello@upf.edu
}

